\title{
EVALUATION OF PHYTOESTROGENS AS A THERAPEUTIC ALTERNATIVE TO HORMONE REPLACEMENT THERAPY (HRT) IN POSTMENOPAUSAL WOMEN
}

\author{
Subhi Vithal ${ }^{1}$
}

${ }^{1}$ Assistant Professor, Department of Obstetrics and Gynaecology, Rama Medical College, Mandhana, Kanpur.

\section{ABSTRACT}

\section{BACKGROUND}

Even in today's scenario, post-menopausal women are blindly treated with Hormone Replacement Therapy to alleviate the symptoms without proper judgment of its side effects. This study was carried to evaluate the role of phytoestrogens as a therapeutic alternative to Hormone Replacement therapy in post-menopausal women.

\section{MATERIALS AND METHODS}

This prospective study was carried in the Department of Obstetrics \& Gynaecology, Rama Medical Collage Hospital \& Research Centre, Mandhana, Kanpur, to evaluate the role of phytoestrogens as a therapeutic alternative to Hormone Replacement therapy in post-menopausal women, 90 symptomatic post-menopausal women with both natural and surgical menopause with symptoms related to menopausal syndrome were selected. All 90 selected post-menopausal women were administered with a regular dose of phytoestrogen namely soy Isoflavones for a period of 6 months. The cases were followed-up and severity of symptoms were studied regularly for a time of 6 months.

\section{RESULTS}

Out of 90 cases regular treatment was observed in 75 cases, while 6 cases took irregular treatment, 5 cases stopped treatment and 4 cases failed to follow up. All the 75 regular cases showed substantial improvement in symptoms like vasomotor symptoms, insomnia, depression, lethargy, etc. Maximum benefit was found in hot flushes, insomnia, depression, lethargy and vaginal dryness.

\section{CONCLUSION}

Though the results of our study was highly encouraging and comparable with earlier studies, the significant role of phytoestrogen over HRT cannot be fully established, but a repeated study over larger count of patients and increased duration of therapy can prove superior role of phytoestrogen over HRT, without any side effects.

\section{KEYWORDS}

Phytoestrogens, Hormone Replacement Therapy, Vasomotor Symptoms, Menopause.

HOW TO CITE THIS ARTICLE: Vithal S. Evaluation of phytoestrogens as a therapeutic alternative to hormone replacement therapy (HRT) in postmenopausal women. J. Evolution Med. Dent. Sci. 2016;5(103):7587-7591, DOI: 10.14260/jemds/2016/1716

\section{BACKGROUND}

Menopause is defined as a permanent cessation of menses for one year. It is a beginning of an era in the life of a woman, which is associated with physical, mental and psychological changes. ${ }^{(1)}$

Menopause is often associated with large number of troublesome symptoms like hot flushes, night sweats, insomnia, mood fluctuation, vaginal atrophy, urinary symptoms, repeated urinary tract infections (UTI), memory impairment, skin changes, weight gain, osteoporosis, cardiovascular diseases, etc.(2)

To relieve symptoms, Hormone Replacement Therapy (HRT) has been advocated for long. Though extremely beneficial, it has certain side effects and limitations, which include abnormal bleeding per vaginum, nausea, vomiting, headache, migraine, oedema, weight gain, derangement of carbohydrate and lipid metabolism.

Financial or Other, Competing Interest: None.

Submission 20-11-2016, Peer Review 13-12-2016,

Acceptance 20-12-2016, Published 26-12-2016.

Corresponding Author:

Dr. Subhi Vithal,

Asha Nursing Home,

\#122/455,

Shastri Nagar, Kanpur.

E-mail: subhi224varyani@gmail.com

DOI: $10.14260 /$ jemds/2016/1716

\section{(c) (i) $\odot$}

Also, there is increased risk of carcinoma breast and carcinoma endometrium. It is also contraindicated in many conditions like uncontrolled hypertension, diabetes mellitus, active liver disease, history of thromboembolism, known coronary heart disease, migraine, endometrial hyperplasia, etc. (1)

In search of a safe agent in place of HRT, Selective Estrogen Receptor Modulators (SERMs) have been developed. Amongst them, phytoestrogens have emerged as a promising alterative to HRT. Phytoestrogens are plantderived compounds that exert both estrogenic and antiestrogenic effects. There are seven classes of phytoestrogens out of which isoflavones are most commonly used.(2)

Most of the Indian postmenopausal women do not come forward for investigations and followup. Unsupervised HRT may be dangerous for our population. Phytoestrogens, though less effective are claimed to be devoid of complications and side effects. So for our population, phytoestrogens appear to be a promising alternative to HRT. Therefore, we planned to study the efficacy and side effects of phytoestrogens on symptomatic postmenopausal women. ${ }^{(3)}$

\section{MATERIALS \& METHODS}

The present study was conducted over a period of 12 months from August 2015 to July 2016 in the Department of 
Obstetrics \& Gynaecology, Rama Medical College Hospital \& Research Centre, Mandhana, Kanpur.

\section{Selection of Patients}

90 symptomatic post-menopausal women with both natura and surgical menopause with symptoms related to menopausal syndrome, coming to outpatient department were selected. All women were counselled about the various treatment options including HRT \& phytoestrogens, advantages, limitations and side effects of HRT and phytoestrogens were explained to them and women who chose phytoestrogens were included in the study. $(3,4,5,6)$

\section{Inclusion Criteria}

1. Symptomatic patients with natural menopause for at least one year.

2. Symptomatic patients with surgical menopause (Total Abdominal Hysterectomy with Bilateral Salpingooophorectomy) at least 3 months prior to entry.

3. Women who were unwilling or unsuitable for conventional HRT.

\section{Exclusion Criteria}

1. Asymptomatic women.

2. Women not willing for treatment.

3. Women who cannot come for followup.

4. Women already taking HRT.

5. Undiagnosed genital bleeding.

6. Known or suspected malignancy.

7. Active infections (UTI, infective vaginitis/vulvitis, etc.).

8. Other acute medical/surgical illness

\section{Study Procedure}

An informed written consent was obtained from each patient after explaining them treatment pattern and follow-up schedule. Detailed medical and gynaecological history was obtained. Detailed general, systemic, breast, local and gynaecological examination and Pap smear was done in all cases and recorded in the worksheet. If any abnormality was found, the case was excluded from the study. All the women included in the study were prescribed $75 \mathrm{mg}$ isoflavone once a day preferably with milk for a period of 6 months. ${ }^{(6,7)}$

\section{Symptoms were divided into Six Groups}

1. Vasomotor- hot flushes, night sweats.

2. Psychological- insomnia, irritability, depression, lethargy.

3. Genital symptoms- vaginal dryness, vaginal irritation.

4. Sexual dysfunction- dyspareunia, loss of libido.

5. Musculoskeletal- muscle, bone and joint pains.

6. Urinary- burning, hesitancy, incontinence, frequency.

Symptoms were graded on a four-point scale according to severity. $\left.{ }^{8,9,10,11}\right)$

Scale
$0-$ None
$1-$ Mild
$2-$ Moderate
$3-$ Severe

\section{Investigations}

Haemoglobin level, urine routine and microscopy, fasting and postprandial blood sugar, lipid profile and transvaginal sonography for endometrial thickness were done in all cases. If any abnormality detected, they were excluded from the study.

The findings were recorded in the format and all women were followed at 3 and 6 months. On each follow-up, they were assessed for-

a) Symptom score.

b) General examination.

c) Breast examination.

d) Gynaecological examination.

e) Investigations- Lipid profile and transvaginal sonography- for endometrial thickness. (At the end of six months).

The results were obtained, observed and subjected to standard statistical analysis to reach a final outcome.

\section{RESULTS}

There was significant decrease in hot flushes, lethargy, vaginal dryness and irritation, muscle bone and joint pains at 3 months. At six months, hot flushes, vaginal dryness and burning micturition further improved. Rest of symptoms were more or less the same as they were at 3 months. Increasing the duration of therapy did not help in improving all the symptoms but was beneficial in some. $(12,13,14)$

\begin{tabular}{|c|c|c|c|c|}
\hline Symptoms & $\begin{array}{c}\mathbf{0} \\
\text { (Months) }\end{array}$ & $\begin{array}{c}\mathbf{3} \\
\text { (Months) }\end{array}$ & $\begin{array}{c}\mathbf{6} \\
\text { (Months) }\end{array}$ & $\begin{array}{c}\text { P value at } \\
\text { 6 Months }\end{array}$ \\
\hline Vasomotor & $\begin{array}{c}67 \\
(99.6 \%)\end{array}$ & $\begin{array}{c}57 \\
(69.3 \%)\end{array}$ & $\begin{array}{c}52 \\
(69.3 \%)\end{array}$ & 0.000 \\
\hline Insomnia & $\begin{array}{c}31 \\
(41.3 \%)\end{array}$ & $\begin{array}{c}29 \\
(38.6 \%)\end{array}$ & $\begin{array}{c}28 \\
(37.3 \%)\end{array}$ & 0.103 \\
\hline Irritability & $\begin{array}{c}51 \\
(68.1 \%)\end{array}$ & $\begin{array}{c}49 \\
(65.31 \%)\end{array}$ & $\begin{array}{c}49 \\
(65.3 \%)\end{array}$ & 0.567 \\
\hline Depression & $\begin{array}{c}11 \\
(14.6 \%)\end{array}$ & $\begin{array}{c}9 \\
(12.0 \%)\end{array}$ & $\begin{array}{c}7 \\
(9.3 \%)\end{array}$ & 0.024 \\
\hline Lethargy & $\begin{array}{c}57 \\
(76.0 \%)\end{array}$ & $\begin{array}{c}47 \\
(62.6 \%)\end{array}$ & $\begin{array}{c}46 \\
(61.3 \%)\end{array}$ & 0.001 \\
\hline Vaginal Dryness & $\begin{array}{c}47 \\
(57.3 \%)\end{array}$ & $\begin{array}{c}42 \\
(45.3 \%)\end{array}$ & $\begin{array}{c}37 \\
(42.6 \%)\end{array}$ & 0.002 \\
\hline $\begin{array}{c}\text { Hesitancy in } \\
\text { Maturation }\end{array}$ & $\begin{array}{c}8 \\
(10.3 \%)\end{array}$ & $\begin{array}{c}6 \\
(8.6 \%)\end{array}$ & $\begin{array}{c}6 \\
(8.6 \%)\end{array}$ & 0.321 \\
\hline $\begin{array}{c}\text { Urinary } \\
\text { Incontinence }\end{array}$ & $\begin{array}{c}16 \\
(14.4 \%)\end{array}$ & $\begin{array}{c}14 \\
(10.56 \%)\end{array}$ & $\begin{array}{c}14 \\
(10.56 \%)\end{array}$ & 0.159 \\
\hline $\begin{array}{c}\text { Frequency of } \\
\text { Micturition }\end{array}$ & $\begin{array}{c}13 \\
(18.10 \%)\end{array}$ & $\begin{array}{c}9 \\
(12.25 \%)\end{array}$ & $\begin{array}{c}7 \\
(10 \%)\end{array}$ & 0.024 \\
\hline $\begin{array}{c}\text { Burning } \\
\text { Micturition }\end{array}$ & $\begin{array}{c}32 \\
(28.8 \%)\end{array}$ & $\begin{array}{c}26 \\
(19.5 \%)\end{array}$ & $\begin{array}{c}24 \\
(81.0 \%)\end{array}$ & 0.004 \\
\hline $\begin{array}{c}\text { Sexual } \\
\text { Dysfunction }\end{array}$ & $\begin{array}{c}45 \\
(60.0 \%)\end{array}$ & $\begin{array}{c}42 \\
(56.0 \%)\end{array}$ & $\begin{array}{c}42 \\
(56.0 \%)\end{array}$ & 0.083 \\
\hline $\begin{array}{c}\text { Muscle, Bone } \\
\text { and Joint Pains }\end{array}$ & $\begin{array}{c}42 \\
(56.0 \%)\end{array}$ & $\begin{array}{c}35 \\
(46.6 \%)\end{array}$ & $\begin{array}{c}34 \\
(45.3 \%)\end{array}$ & 0.002 \\
\hline $\begin{array}{c}\text { Table 1. Effect of Phytoestrogens on the Incidence of } \\
\text { Post-menopausal Symptoms (In percentage) (n=75) }\end{array}$ \\
\hline
\end{tabular}




\begin{tabular}{|c|c|c|c|c|}
\hline $\begin{array}{l}\text { Symptoms } \\
\text { (Mean) }\end{array}$ & $\begin{array}{c}0 \\
\text { (Months) }\end{array}$ & $\begin{array}{c}3 \\
\text { (Months) }\end{array}$ & $\begin{array}{c}6 \\
\text { (Months) }\end{array}$ & $\begin{array}{c}\text { P value } \\
\text { at } 6 \text { Months }\end{array}$ \\
\hline Vasomotor & 2.1 & 1.6 & 1.1 & 0.000 \\
\hline Insomnia & 0.89 & 0.75 & 0.49 & 0.000 \\
\hline Irritability & 1.44 & 1.27 & 1.22 & 0.026 \\
\hline Depression & 0.54 & 0.34 & 0.27 & 0.040 \\
\hline Lethargy & 1.47 & 1.38 & 1.18 & 0.000 \\
\hline $\begin{array}{c}\text { Vaginal } \\
\text { Dryness } \\
\text { Irritation }\end{array}$ & 1.33 & 0.95 & 0.75 & 0.000 \\
\hline $\begin{array}{l}\text { Hesitancy in } \\
\text { Micturition }\end{array}$ & 1.07 & 1.02 & 1.02 & 0.083 \\
\hline $\begin{array}{c}\text { Urinary } \\
\text { Incontinence }\end{array}$ & 1.40 & 0.090 & 0.090 & 0.002 \\
\hline $\begin{array}{l}\text { Frequency } \\
\text { Micturition }\end{array}$ & 1.50 & 1.01 & 0.08 & 0.015 \\
\hline $\begin{array}{c}\text { Burning } \\
\text { Micturition }\end{array}$ & 2.08 & 1.90 & 1.75 & 0.000 \\
\hline $\begin{array}{c}\text { Sexual } \\
\text { Dysfunction }\end{array}$ & 1.50 & 1.31 & 1.25 & 0.083 \\
\hline $\begin{array}{c}\text { Muscle, } \\
\text { Bone and } \\
\text { Joint Pains }\end{array}$ & 1.16 & 1.12 & 1.07 & 0.057 \\
\hline $\begin{array}{r}\text { Table } \\
\text { of }\end{array}$ & $\begin{array}{l}\text { ffect of } \\
\text { st-men }\end{array}$ & $\begin{array}{l}\text { toestrc } \\
\text { usal Sy }\end{array}$ & $\begin{array}{l}\text { on the } \\
\text { oms (n }\end{array}$ & verity \\
\hline
\end{tabular}

At 3 months, there was significant decrease in the mean score of severity of vasomotor symptoms, insomnia, depression, lethargy, vaginal dryness and burning micturition. Severity score further decreased at 6 months in all symptoms except hesitancy and urinary incontinence. Maximum benefit was found in hot flushes, insomnia, depression, lethargy and vaginal dryness. Hence, prolonging therapy helps in reducing the severity of symptoms.

\begin{tabular}{|c|c|c|}
\hline Side Effects & Number & Percentage \\
\hline Bloating & 07 & 9.0 \\
\hline Weight Gain & - & - \\
\hline Nausea & - & - \\
\hline Epigastria Pain & - & - \\
\hline Oedema Hand \& Feet & - & - \\
\hline Breast Discomfort & - & - \\
\hline Leg Cramps & - & - \\
\hline Others & - & - \\
\hline \multicolumn{2}{|c|}{ Table 3. Side Effects of Phytoestrogens (n=75) } \\
\hline
\end{tabular}

No disturbing side effects were observed by any of the case. Only $9 \%$ women had minimal bloating which was acceptable to them. Most of the women were free from fear of long term complications like malignancy and weight gain. $\left({ }^{15,16}\right)$

\section{DISCUSSION}

Recently, there has been a global effort to find alternative and natural treatments for menopause, so phytoestrogens prove as an attractive addition to the choices available for the treatment of postmenopausal syndrome. In our study, 90 postmenopausal cases with both surgical and natural menopause were given a phytoestrogen preparation to alleviate these symptoms and outcomes were studied for a period of six months.
- Drug was started in maximum number of cases with natural menopause for 1-2 years and with surgical menopause 1.5-2 years which was comparable.

- Compliance was less in our study. Out of 90 cases, 75 cases took regular treatments for six months, whereas 6 took irregularly, 5 cases stopped treatment on their own and loss to follow up was seen in 4 cases.

- $\quad$ The average figures of climacteric symptoms in the study by Shah et al were comparable to our study. Hot flushes in $86.2 \%$ irritability 69.2 , depression $53.3 \%$, insomnia $62.4 \%$, sexual dysfunction $62.9 \%$, vulval irritation and dryness $75.9 \%$ and urinary incontinence $60 \%$, cases. Urinary incontinence and depression was less in our study.

- In our study, $75 \mathrm{mg}$ isoflavone was prescribed per day for six months while Albert et al, gave $70 \mathrm{mg}$ per day for 4 months, which was comparable to our study whereas Upmalis et al used a lower dose of $50 \mathrm{mg}$ per day for six months in 177 women.

- The incidence of hot flushes decreased from $88.6 \%$ to $69.3 \%$ (20\% reduction) at the end of six months which was highly significant $(\mathrm{P}=0.000)$ while the mean number of hot flushes decreased from 11.12 to 8.61 and the severity score decreased from 2.1 to $1.1(\mathrm{P}=0.000)$. Upmalis et al reported 25\% reduction in the frequency and severity of hot flushes which was comparable to our study whereas study by Albertazzi et al showed a very high decrease in the number of hot flushes up to 1.59 fold.

- Insomnia decreased from $41.3 \%$ to $37.3 \%$ which was statistically not significant but the severity score decreased from 0.89 to 0.49 which was significant $(\mathrm{P}=0.000)$. Similar findings were given by Drew and Puk. Singh et al showed 83\% improvement in the incidence of insomnia but there were only 29 women in their study, 169 in the study by Drew et al and 75 in our study.

- Psychological symptoms like irritability showed little improvement of $2.7 \%$ which was not statistically significant and severity score dropped from 1.44 to 1.22 $(\mathrm{P}=0.026)$ whereas $\mathrm{Shah}$ et al reported a significant reduction of $19 \%$.

- The incidence of depression dropped from $11 \%$ to $7 \%$ and severity score from 0.54 to 0.27 which was not statistically significant while the study by Shah et al showed $43 \%$ improvement.

- The incidence of lethargy decreased from $76 \%$ to $61 \%$ and severity score 1.47 to $1.18(\mathrm{P}=0.000)$ which was highly significant. Shah et al also showed similar findings.

- In our studies, there was decrease in the incidence of vaginal dryness and irritation from $47 \%$ to $37 \%$ and severity score from 1.33 to $0.75(\mathrm{P}=0.000)$ which was highly significant and the findings were comparable to study by Han et al.

- The incidence of sexual dysfunction (loss of libido and dyspareunia) decreased from $45 \%$ to $42 \%$ while the severity dropped from 1.51 to 1.25 which was not significant as many of the cases were not sexually active or widows.

- There was decrease in the incidence of urinary symptoms but were statistically not significant. 
- The incidence of muscle, bone and joint pains dropped from $56 \%$ to $45.3 \%(\mathrm{P}=0.002)$ which was statistically significant and the severity dropped from 1.16 to 1.07 . These findings were similar to Singh et al.

- The overall improvement in the menopausal symptoms observed in the present study were consistent with the finding of Murkies et al, who reported decrease in symptom score of hot flushes, sleep disturbance, depression, tiredness, irritability and urogenital symptoms.

- Also, there was no significant variation in the lipid profile in the endometrial thickness.

- No distressing side effects were noticed by any of the women except bloating in $9 \%$ women which was acceptable to them.

- In our study, we have not compared the results with placebo or HRT. Also, the symptoms were assessed subjectively. So possibility of bias cannot be ruled out. Therefore, further double blind long term trials are required before recommending phytoestrogens as first line therapy in symptomatic postmenopausal women.

\section{CONCLUSION}

The present study entitled "Evaluation of Phytoestrogens as a Therapeutic Alternative to Hormone Replacement Therapy in Post-menopausal Women" was conducted in the Department of Obstetrics \& Gynaecology of Rama Medical College Hospital \& Research Centre, Mandhana, Kanpur, over a period of 12 months from August 2015 to July 2016 to evaluate the efficacy and side effects of Phytoestrogens.

- 90 cases were enrolled for the study with both natural and surgical menopause, out of which 75 cases could complete the follow-up schedule.

- Hot flushes were seen in maximum cases i.e. $88.6 \%$, followed by lethargy in $76 \%$, irritability $68.1 \%$ and sexual dysfunction in $60 \%$.

- Phytoestrogens significantly reduced the incidence of vasomotor symptoms (19.3\%), insomnia (4\%), lethargy (11\%), vaginal dryness (10\%), hesitancy (1.7\%), burning micturition $(10.8 \%)$ and muscle, bone and joint pains $(8 \%)$ after six months of regular therapy. $\left(^{16,17,18,19}\right)$

- There was statistically significant drop in severity score at 6 months in vasomotor symptoms (1.0), insomnia (0.40), lethargy (0.29), vaginal dryness (0.48) and burning micturition (0.33).

- There was no significant variation in average body weight, blood pressure and lipid profile at the end of 6 months which implies the potential cardioprotective effect. ${ }^{20,21,22}$ )

- There was no significant variation in the endometrial thickness in 6 months which is a cancer protective sign. Therefore, to conclude, a good response was seen in most of therapy but prolonging the therapy for 6 months of reduced the severity score in most of the symptoms.

- In 6 month follow-up, no side effects were noticed except for mild bloating. Thus, phytoestrogenic preparations provide an attractive option for the management of postmenopausal symptoms and are free of side effects. $(23,24)$

- $\quad$ There is yet no definitive information in literature about the optimum dose and long term side effect. Therefore, further long term double blinded multicentric trials are required before reaching to a definite conclusion. But in Indian scenario where postmenopausal women do not come for follow-up and investigations, phytoestrogens presently appear to be a safe and effective alternative. $(25,26,27)$

\section{REFERENCES}

[1] Hurd WW, Amsse LS, Randolph JF Jr. Menopause. In: Berek JS, eds. Novak's gynaecology. $13^{\text {th }}$ edn. Philadelphia: Lippincott Williams \& Wilkins 2002:110939.

[2] Speroff L, Glass RH, Kase NG. Menopause and the perimenopausal transition. Clinical, gynaecologic endocrinology \& infertility. $6^{\text {th }}$ edn. Philadelphia: Lippincott Williams \& Wilkins 1999:650-77.

[3] Marwick C. Growing use of botanicals forces assessment by drug regulators. JAMA 1995;273(8):607-9.

[4] Seaman B. The greatest experiment ever performed on women: exploding the estrogen myth. New York: Hyperion 2003.

[5] Perls TT, Fretts RC. The evolution of menopause and life span. Ann of Hum Biol 2001;28(3):237-245.

[6] Carlson KJ, Eisenstat SA, Ziporyn TD, et al. The new Harvard guide to women`s health. Cambridge, MA: Harvard University Press 2004:p. 357.

[7] Longcope C, Franz C, Morello C. Steroid \& gonadotropin levels in women during the peri-menopausal years. Maturitas 1968;8(3):189-96.

[8] Kronenberg F. Hot flashes: phenomenology, quality of life \& search for treatment options. Exp Gerontol 1994;29(3-4):319-36.

[9] Bachmann G. Urogenital ageing: an old problem newly recognized. Maturitas 1995;22(Suppl):S1-S5.

[10] Bachmann GA, Ebert G, Burd ID. Vulvovaginal complaints. Women basic and clinical aspects. $2^{\text {nd }}$ edn. Philadelphia, PA: Lippincott Williams \& Wilkins 1999;195-201.

[11] Seeman E. Pathogenesis of bone fragility in women \& men. Lancet 2002;359(9320):1841-50.

[12] Patel MA, Khadilkar SS. Postmenopausal osteoporosis. In: Purandare CN, Khadikar SS, eds. Menopause current concepts. 1st edn. New Delhi: Jaypee Brothers 2004:p. 42-6.

[13] Kanis JA. Diagnosis of osteoporosis and assessment of fracture risk. Lancet 2002;359(9321):1929-36.

[14] Metlon LJ lll. Who has osteoporosis? A conflict between clinical and public health perspectives. J Bone Miner Res 2000;15(12):2309-14.

[15] Kannel WB. Metabolic risk factors for coronary heart disease in women: perspective from the Framingham Study. Am Heart J 1987;114(2):413-9.

[16] Mendelsohn ME, Karas RH. The protective efforts of estrogen on the cardiovascular system. N Engl J Med 1999;340(23):1801-11.

[17] North American Menopause Society. Treatment of menopause-associated vasomotor symptoms: position statement of the north American menopause society. Menopause 2004;11(1):11-13.

[18] McNagny SE. Prescribing hormone replacement therapy for menopausal symptoms. Ann lntern Med 1999;131(8):605-16. 
[19] Nilsson K, Risberg B, Heimer G. The vaginal epithelium in the postmenopause--cytology, histology and $\mathrm{pH}$ as methods of assessment. Maturitas 1995;21(1):51-6.

[20] Evio S, Tiitinen A, Laitinen $K$, et al. Effects of alendronate and hormone replacement therapy, alone and in combination, on bone mass and markers of bone turnover in elderly women with osteoporosis. J Clin Endocrinal Metab 2004;89(2):626-31.

[21] Manson JE, Martin KA. Clinical practice. Postmenopausal hormone-replacement therapy. $N$ Engl J Med 2001;345(1):34-40.

[22] Barrett-Connor E. Putative complication of estrogen replacement therapy. Hypertension, diabetes, thrombophlebitis and gallstones. In: Korenman SG, ed. The menopause: biological and clinical consequences of ovarian failure: evolution and management. Norwell, MA: Serono Symposia 1990;199-209.
[23] Barrett-Conner E, Slone S, Greendale G, et al. The postmenopausal estrogen/progestin interventions study: primary outcomes in adherent women. Maturitas 1997;27(3):261-74.

[24] Ziel HK, Finkle WD. Increased risk of endometrial carcinoma among uses of conjugated estrogens. New England Journal of Medicine 1975;293:1167-70.

[25] Boston Collaborative Drug Surveillance Program. Surgically confirmed gallbladder disease, venous thromboembolism and breast tumors in relation to post-menopausal estrogen therapy. New England Journal of Medicine 1974;290:15-9.

[26] Hoover R, Gray LA, Cole P. Menopausal estrogens and breast cancer. New England Journal of Medicine 1976;295:401-5.

[27] Beral V, Million Women Study Collaborators. Breast cancer and hormone-replacement therapy in the million women study. Lancet 2003;362(9382):419-27. 